week there was only a very occasional whoop, no hurried respiration, and no expectoration. Improvement in such cases is marked by the decline in the numbers of nightly paroxysms; this fall frequently takes place very abruptly, and it is not unusual, in a case where hourly paroxysms have been the rule at night, to hear that the child has slept four hours right off without a paroxysm. This sudden improvement occurs about the small hours of the morning, and is maintained, unless relapse takes place, and the interval is steadily increased to six, seven, or eight hours.

Whooping-cough has many specifics. Belladonna I have been disappointed in, but have never pushed it to very large doses, though $I$ have pressed it to moderately large ones, as it is difficult in private practice to see the patient sufficiently often to watch that the physiological effect of the drug has not been exceeded. I have settled down for the most part into the treatment of uncomplicated cases with nitric acid and bromide of ammonium, combined with bark, and probably ipecacuanha or squills, with the external application of a stimulating liniment to the chest, back, and spine. In the condition $I$ have described, exclusive specific treatment is for the most part disappointing. In its early stages, carbonate of ammonia, combined with a diminished dose of bromide, is of service with tolu and senega; the dose of the bromide should be a diminished one, as some authorities on the subject have pointed out, as, if given in the larger doses in this complication of the disease, the tendency to drowsiness is increased. Possibly with this treatment we may remove the bronchitis and return to the direct specific treatment. Frequently, however, notwithstanding the stimulating expectorant, the respiration becomes quicker; the secretion from the bronchial tubes, though dislodged in considerable quantity, seems to be secreted in increased amount, and accumulates in the tubes. I wish to direst attention to the treatment I have found most serviceable in such cases. I give two mixtures, each every six hours, the one within three hours of the other: the first containing oil of turpentine, spirit of ether, and tolu ; the second containing a large dose of dilute nitric acid, a small dose of bromide of ammonium, with senega and bark. I find this treatment most efficacious; the turpentine dislodges the secretion and acts as a stimulant, the ether relieves the spasm and also stimulates, and the nitric acid comes into play as a specific. More reliance, I believe, is to be placed upon the nitric acid than the bromide for diminishing the number and duration of the paroxysms, but I have not found it useful when bronchitis is present, unless in a considerable dose. For a child of five years I give up to ten minims of the dilute acid for a dose. I have not found any untoward result from this or from the turpentine, which $I$ give in about five-minim doses for a child of the same age. As auxiliary treatment, I keep the chest and back wrapped up in cotton-wool, and order to be rubbed in two or three times a day a combination of compound camphor and soap liniment. It is wonderful how a child's skin gets accustomed to its use, and a child of five years will tolerate an application containing one-third and sometimes one-half of the compound camphor liniment without flinching, or without vesication, or even much erythema resulting. Such foods should be given as are quickly assimilated, and should be administered as soon as a paroxysm is over. Stimulants are of immense service given with discretion in the presence of the drowsiness, as there is much exhaustion from the frequency of the paroxysms, the long duration of the disease, and frequently the starvation, so little food being allowed to remain in some cases in the stomach. When improvement has taken place cod-liver oil is of great service, also quinine and iron, either separately or combined, followed up by the usual change of air.

I am indebted to Dr. Hickman, of Dorset-square, N.W., for much valuable information as to the treatment of this most rebellious ailment.

Eckington, Derbyshire.

SURGEONS WANTED FOR THE WAR.-The Servian Minister has received from Belgrade an official telegram to the following effect:- "The Servian Government would thankfully receive the medical services of English surgeons and doctors. All desiring to offer their services to the $R$ ed Cross are requested to address their offer to the Chief Commissioner of the Red Cross, Colonel Dr. Sava, Petrovich, Belgrade."

\section{A CASE IN WHICH FOUR TAPEWORMS COEXISTED IN ONE PERSON.}

By THEOBALD A. PAL M, M.A., M.D., LATE MEdical Misstonari IN Japax.

As supplementary to the list of cases by Dr. Cobbold in THE LANCET of Sept. 26th illustrating the value of male shield fern in the treatment of tænia, the following case may be of interest, partly because it is an unusual occurrence to find several tapeworms coexisting, and also because it illustrates the importance in treatment of not only looking for the head of the parasite, but also of examining the whole of the parasite evacuated.

A German gentleman resident in Niigata, Japan, had suffered from tapeworm for more than twelve years, and had undergone a variety of treatment without avail, having, as he informed me, at one time eaten a large plateful of boiled pomegranite-root. I prescribed for him eighty minims of the ethereal extract of male fern, to be taken on awaking in the morning after fasting from noon of the previous day. It was taken in milk, in three portions, at short intervals, and the recumbent position was maintained till nausea had passed away. I had explained to him the importance of finding the head, and described what it was like. Later in the day he brought me in triumph two heads in a small phial and a large quantity of tapeworm. Upon arranging this around a large tray in lengths, I found that there was more than could be accounted for by two tapeworms, there being an array of the narrow segments near the head, beside those belonging to the two heads already evacuated. He was somewhat incredulous when $I$ informed him that he had another left in him. After some weeks, however, he paid me a further visit, as he was again passing proglottides. The male fern was administered as before, bringing away one head and a considerable length of the worm. Upon examining this, and carefully putting it together on a tray, I again found that there were two lengths of the narrow upper portion of the parasite, which evidently belonged to separate worms. My patient delayed treatment until there was indisputable evidence that he was not cured, and then a third dose of the same remedy brought away the fourth and last head. I may add that his health did not appear in any way to suffer from the presence of the four tapeworms. His appetite was somewhat improved by the presence of the four guests whom he entertained, but this was a symptom of which he did not complain. He sought relief from the annoying consciousness of being the victim of a repulsive parasite.

Thorncombe, chard.

\section{A}

\section{HOSPITAL PRACTICE, BRITISH AND FOREIGN.}

Nulla autem est alia pro certo noscendi via, nisi quamplurimas et mor borum et dissectionum historias, tum aliorum tum proprias collectas habere, et inter se comparare.-MoRGAGNI De Sed. et Caus. Morb. lib. iv. Procmium.

\section{ROYAL HOSPITAL FOR WOMEN AND CHILDREY.}

IAARE UTKRINE MYO-FIBROMA; PROFLSE METRORRHAGIA ; ATTEMPTED REMOVAT OF OVARIES; REATOVAL OF UTERUS WITH TUMOUR; SECONDARY HEMORRHAGE FROM PEDICLE; DEATH FROM CARDIAC THROMBOSIS.

(Under the care of Dr. WILLIAM DLNCAN.)

THE following case will be read with interest, not so much from its unusual character as from the accident which occurred in the breaking of the wire of the serrenœud-an accident which has fortunately been of very rare occurrence, but which involves very serious consequences to the patient. Some remarks on the case are appended by Dr. Duncan, to which we would refer our readers.

Mrs. P_- aged thirty-two, was admitted into the hospital on March 19th, 1885. Has been married thirteen years ; × 2 